This item was submitted to Loughborough's Research Repository by the author.

Items in Figshare are protected by copyright, with all rights reserved, unless otherwise indicated.

\title{
The evaluation criteria used by venture capitalists: evidence from a UK venture fund
}

PLEASE CITE THE PUBLISHED VERSION

http://dx.doi.org/10.1177/0266242697161003

PUBLISHER

(c) Sage Publications

VERSION

AM (Accepted Manuscript)

LICENCE

CC BY-NC-ND 4.0

REPOSITORY RECORD

Boocock, Grahame, and Margaret Woods. 2019. "The Evaluation Criteria Used by Venture Capitalists: Evidence from a UK Venture Fund”. figshare. https://hdl.handle.net/2134/7666. 
This item was submitted to Loughborough's Institutional Repository (https://dspace.lboro.ac.uk/) by the author and is made available under the following Creative Commons Licence conditions.

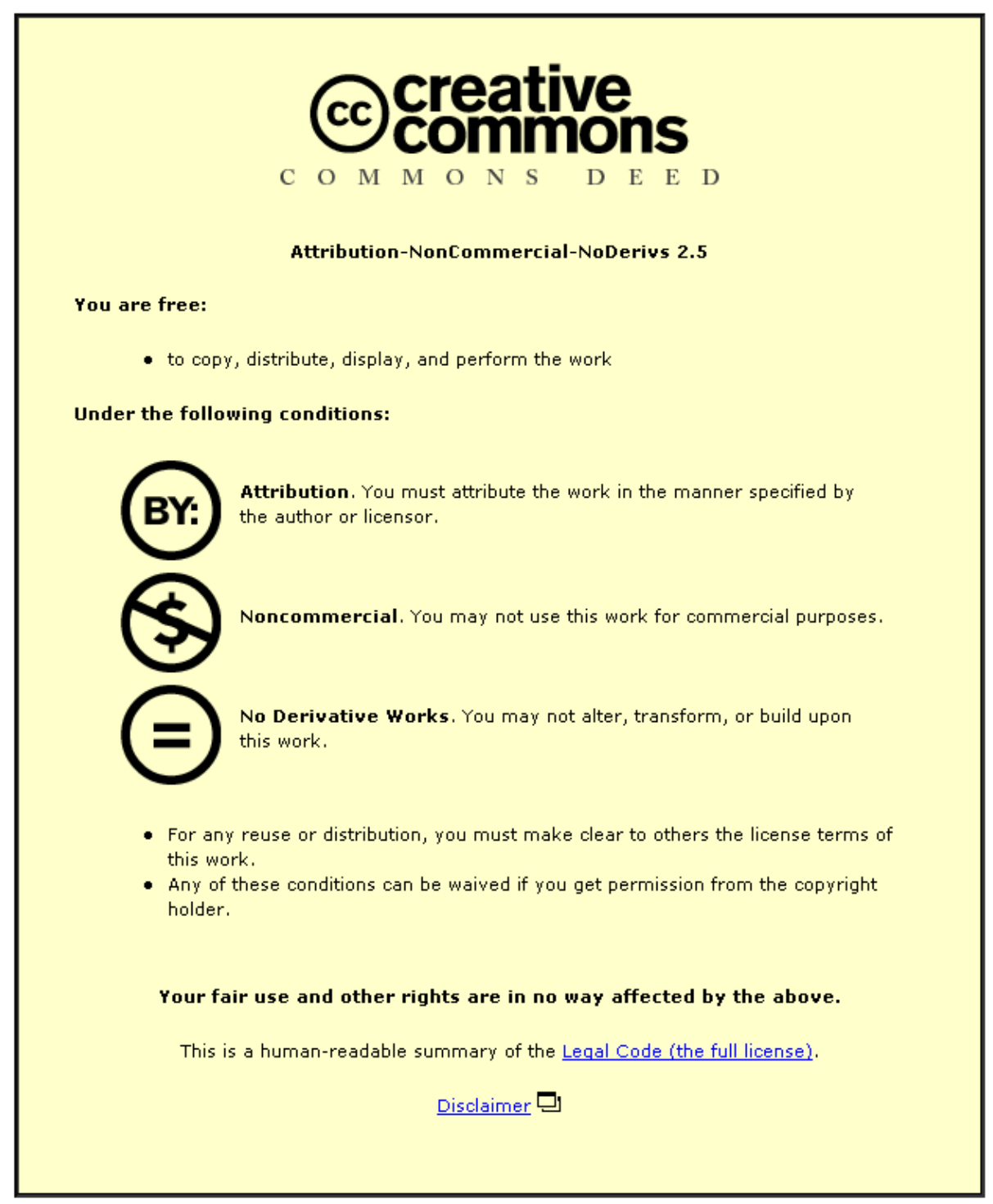

For the full text of this licence, please go to: http://creativecommons.org/licenses/by-nc-nd/2.5/ 


\title{
The Evaluation Criteria used by Venture Capitalists: Evidence from a UK Venture Fund
}

\author{
Grahame Boocock and Margaret Woods
}

Grahame Boocock and Margaret Woods are Lecturers in Banking and Finance, and Financial Management, respectively at Loughborough University Business School, England. The paper examines how venture fund managers select their investee companies, by exploring the evaluation criteria and the decision making process adopted at one UK Regional Venture Fund (henceforth referred to as the Fund). The analysis confirms that relatively consistent evaluation criteria are applied across the industry and corroborates previous models which suggest that venture capitalists' decision making consists of several stages. With the benefit of access to the Fund's internal records, however, this paper adds to the current literature by differentiating the evaluation criteria used at each successive stage of the decision-making process. The paper presents a model of the Fund's activities which demonstrates that the relative importance attached to the evaluation criteria changes as applications are systematically processed. Proposals have to satisfy different criteria at each stage of the decision-making process before they receive funding. In the vast majority of cases, applications are rejected by the fund managers. In addition, the length of time taken by the fund managers in appraising propositions can lead to the withdrawal of applications at an advanced stage. 
Lorenz (1989, p5) defines venture capital as long-term, equity-based risk finance where the primary reward for the investor is capital gain. Such funding seeks out and nurtures high growth entrepreneurial companies which are frequently refused finance from conventional sources (Ray, 1993). On the same theme, Bygrave and Timmons (1992, p1) describe venture capital as playing “... a catalytic role in the entrepreneurial process, (offering) fundamental value creation that triggers and sustains economic growth and revival". However, they also draw a distinction between "classic venture capital", early-stage financing, and "merchant capital", a hybrid that combines classic venture capital with development financing and investments in leveraged and management buy-outs.

UK venture capital investment activity has mirrored the operations of venture fund managers across the world by moving in favour of merchant capital at the expense of smaller value investments in higher risk start-ups (BVCA, various). This trend tends to confirm the widely expressed view that there is a shortage of long-term funding at the lower end of the financing spectrum (Bannock et al., 1991, p31), although it has proved difficult to isolate an "equity gap" in practice (University of Cambridge, 1992). In an attempt to plug this perceived gap in the market, Midland Bank proposed, in the early 1990s, to introduce a number of venture funds concentrating on small investments (McMeekin, 1991). A network of 11 regional enterprise funds was eventually launched in 1992. This paper focuses on the activities of one of the funds, the Midland Enterprise Fund for the East Midlands.

The high costs encountered in providing classic venture capital provided the rationale for the formation of these funds. The costs stem from the requirement to undertake "due diligence" ${ }^{1}$ including credit searches and detailed analysis of the financial viability of the proposition; the charges levied for undertaking this appraisal are often prohibitive in relation to the amount of funding sought. Midland Bank proposed to overcome this cost barrier by persuading accountants, solicitors and other professionals to offer their services at reduced fees. The professional firms would hopefully be compensated for the short-term loss of income by a flow of new clients. This cost cutting was "at the heart of the proposal to bridge the (equity) gap in a commercially viable way" (McMeekin, 1991). 
Another important function of the proposed Midland network was to advise firms on alternative sources of external finance, including the role of informal risk capital provided by private individuals. There is growing evidence that "business angels" have the potential to complement the institutional venture capital market (for example: ACOST, 1990; Mason and Harrison, 1993 and 1994).

Previous research on the venture capital sector has covered such diverse areas as the size and composition of venture fund portfolios, the fate of firms rejected by venture funds and the analysis of how venture capitalists allocate their workload (Fried and Hisrich, 1988). The focus of greatest attention, however, has been the venture capitalist's decision-making process ${ }^{2}$.

Research in this area can be classified under two headings:

- $\quad$ analysis of the investment cycle ${ }^{3}$ as a whole (for example: Tybejee and Bruno, 1984; Silver, 1985; Hall, 1989; Hall and Hofer, 1993; and, Fried and Hisrich, 1994);

- identification of the evaluation/selection criteria ${ }^{4}$ utilised in deciding which applications to reject or accept (for example: Tybejee and Bruno 1984; MacMillan et al., 1985 and 1987; Dixon, 1991; Hall and Hofer, 1993; and, Rah et al., 1994).

Using detailed data from a single fund, the contribution of this paper is to explore the linkages between the two main strands of the literature identified above. The principal aims of the paper, therefore, are:

- $\quad$ to identify the investment cycle and selection criteria used by the Fund in deciding which applications to reject or support ;

- to demonstrate that the selection criteria change as an application progresses through the various stages in the decision-making process. 
The structure of the paper is as follows:

(i) the main features of the Fund are described and the research methodology is outlined

(ii) the Fund's investment cycle and evaluation criteria are identified and compared with those in the existing literature

(iii) a model of the decision-making process is developed for the Fund, linking the selection criteria to the various stages of the decision-making process

(iv) finally, the implications of our findings for both academics and practitioners are discussed.

\section{The Midland Enterprise Fund for the East Midlands}

The Fund has a sum of $£ 1.25 \mathrm{~m}$ to invest, primarily in projects smaller than those backed by other venture funds. The size of deal can range from a minimum of $£ 5,000$ to a maximum of $£ 125,000$, although larger syndicated deals are possible. Investee companies have to be located within the East Midlands (the five counties of Leicestershire, Nottinghamshire, Northamptonshire, Lincolnshire and Derbyshire) and to demonstrate the capacity for rapid growth. The region offers a strongly diversified industrial base, with a growing services sector; its economic performance has remained above average, despite the setback of coalfield closures. The Fund is prepared to invest in companies situated in any industry and at any stage of development, but a maximum of 15 percent of the investment pool is to be devoted to start-ups.

In common with the majority of independent funds, the Fund is structured as a limited partnership. It has a life of ten years, and the intention is to make investments over the first five years of its life, 1992-1997. The investors include Midland Bank, local Training and Enterprise Councils and a number of individuals; all 
investors are motivated by the prospects of commercial gains, and the TECs are also keen to promote SMEs in their catchment areas. The investors have no influence on general investment policy or specific investment decisions. All investment decisions are the responsibility of the fund management company Midlands Venture Fund Managers Limited (MVFML). The Managing Director of MVFML (over the period of this study) was an experienced fund manager with wide knowledge of the venture capital industry; the other directors are prominent local businessmen. A small support team, seconded from Midland Bank, assisted with the assessment of applications.

The Fund is hoping to achieve a rate of return in line with the average for the venture capital industry. The fund managers receive a modest annual fee for operating the Fund, a fee from each investee company on completion of an investment and, in accordance with standard industry practice, there is a "carried interest, profit sharing clause" enabling the fund managers to share in the success of investee companies.

Applications to the Fund were a mix of unsolicited applications and referrals from intermediaries, with the balance over time moving towards the latter. In the first two years of the Fund's life, October 1992 to October 1994, activity was as follows:

Total applications

232

Applications assessed

206

Investments

Rejections

203

Investment ratio

Awaiting decision 


\section{The Research Methodology}

Our approach was to analyse all 232 applications received by the Fund over the first two years of its existence. (For a fuller description of the initial enquiries and applications received by the Fund, see Boocock, Woods and Caley, 1995.) With the full co-operation of MVFML, data were collected in a variety of ways: from semistructured interviews with officials; by classifying the contents of comprehensive working notes and reports on applications; and by analysing statistics on applications rejected and accepted. The data sought was broad-ranging, although the focus was on the evaluation criteria used to judge applications. The frequency of citation of specific criteria enabled the researchers to establish key factors in the decisionmaking process.

This method of data collection removes potential methodological weaknesses acknowledged by MacMillan et al. (1985, p122). The data set is not open to errors and biases arising from self reporting, nor does it rely upon the venture capitalists' ability to recall the factors influencing their decisions. Applications were tracked as they moved through the investment cycle. The material is drawn directly from the Fund's records and, at the time the comments were entered, the managers were not aware that their observations would be used for research purposes. As a result, our data set captures the genuine reactions of the fund managers as meetings were taking place or critical decisions to accept/reject applications were being made.

We believe that this study is unique for the UK. Researchers in the United States have sometimes been able to gain access to venture capitalists' private documents, but this is the exception rather than the rule (Norton, 1993). Our findings would be of little value, nonetheless, if the Fund operated in a "non-standard" way. This does not appear to be the case. Notwithstanding its relatively modest size and focus on smaller deals, the Fund's investment philosophy is entirely governed by commercial considerations.

The Fund's investment ratio of 1.46 percent over the first two years of operations appears to be lower than the industry averages suggested by Sweeting (1991, 
p612), 2 percent, and Bannock (1991, p47), 3.4 percent. A below average figure might have been anticipated, because larger deals are excluded and a high proportion of the initial enquiries and applications to the Fund were of very poor quality. Furthermore, the fund managers were understandably keen to create a "demonstration effect" by backing successful firms, hence it was very important that the first few investments did not fail (Boocock, Woods and Caley, 1995).

Nevertheless, another of the proposals being evaluated at October 1994 resulted in an investment, bringing the Fund's investment ratio up to almost 2 percent. This investment record also compares favourably with other Midland Enterprise Funds. Information obtained on a confidential basis from two funds revealed that, over the equivalent period, they had completed 3 investments from 194 applications (1.54 percent) and 2 investments from 138 applications (1.44 percent) respectively.

\section{The Investment Cycle}

This approach to analysing venture capitalists' operations focuses on the sequential nature of the investment cycle.

In 1984, Tybejee and Bruno described the cycle as an orderly process of five sequential steps: deal origination; screening; evaluation; deal structuring; and postinvestment activities. Silver (1985) refined the above framework by replacing evaluation with due diligence and introducing the concept of cashing out. Hall (1989) increased the number of stages, by the addition of assessment after screening. More recently, Fried and Hisrich (1994) modelled the decision-making process (excluding post-investment activities) in six stages: deal origination; venture capital firm-specific screen; generic screen; first-phase evaluation; second-phase evaluation; and, closing.

The precise number of stages (and the terminology) differs between studies, but there is general agreement that the decision-making process involves at least two stages - screening and evaluation/due diligence - and that the investment cycle consists of multiple stages. A comparison between selected previous studies and the approach taken by this Midland Enterprise Fund is contained in Table 1. 
The investment cycle adopted by the Fund is now described in detail.

1. Generating a Deal Flow: prospective investments emanate from a variety of sources, including unsolicited applications, via intermediaries and referrals from other financial institutions.

2. Initial Screening: the fund management company (MVFML) employs a small number of staff to deal with a relatively large number of applications, hence the screening stage is rapid and the rejection rate high. (This confirmed the findings in a previous UK study, which suggested that the average first reading time for an application is 10-15 minutes: Sweeting, 1991, p610.) In essence, screening consists of a perusal of the business plan in a search for key features which indicate that closer study might be worthwhile.

3. First Meeting: the M/D meets with representatives of the firm, usually at the applicant's business site, to form judgements on, for example, production capacity, marketing plans and the ability of the management team.

4. Second Meeting: further information on the business and its management is obtained. Another director of MVFML leads this meeting, allowing MVFML the opportunity to vet the potential investee company from a different perspective. The second meeting helps to secure the Fund's "emotional commitment" to the proposal (Fried and Hisrich, 1994, p34). It is also vital to ensure that the owners of the firm understand the nature of venture capital.

5. Presentation to Board of Directors: the potential investee company has to make a brief presentation to the full Board, despite the fact that the proposition has been examined by two directors. This step is unusual, allowing all of the Board of directors of the Fund Management Company the opportunity to decide whether a proposal meets the Fund's criteria. 
6. Due Diligence: there is now agreement in principle to provide the finance, hence this stage comprises credit searches on the company (and its owners) and detailed analysis of the financial viability of the proposition; the financial projections form the basis for structuring the deal and eventual realisation of the investment. An unconditional offer of funding is not issued until the due diligence stage is completed.

7. Deal Structuring: the fund managers are prepared to mix equity, convertible instruments and pure loan finance as appropriate. The use of ratchets enables entrepreneurs to reduce the Fund's equity stake in their business if performance targets are met. Negotiations at this stage are critical. Entrepreneurs are very sensitive to what they perceive as the imposition of unfair terms in the funding offer.

8. Ongoing Monitoring of Investments: one of the characteristics of venture finance is an active interest in the performance of investee companies, described as a combination of capital and consulting by Warne (1988). This Fund is no exception. The emphasis is on the free flow of information and ideas, rather than hands-on management. The Fund can take an active management role, however, when either or both parties judge that this course of action is necessary.

9. Cashing Out: it is anticipated that the investments will be realised by trade sale to a larger company, company buy-back or, in very exceptional circumstances, by flotation.

At each stage of the decision-making process (Stages 2-7 for the Fund studied here), the evaluation criteria used by fund managers play a crucial role. An examination of these criteria, the subject of extensive research in the past, forms the basis of the next section of this paper. 
Table 1: Stages of Venture Capitalists' Investment Cycle

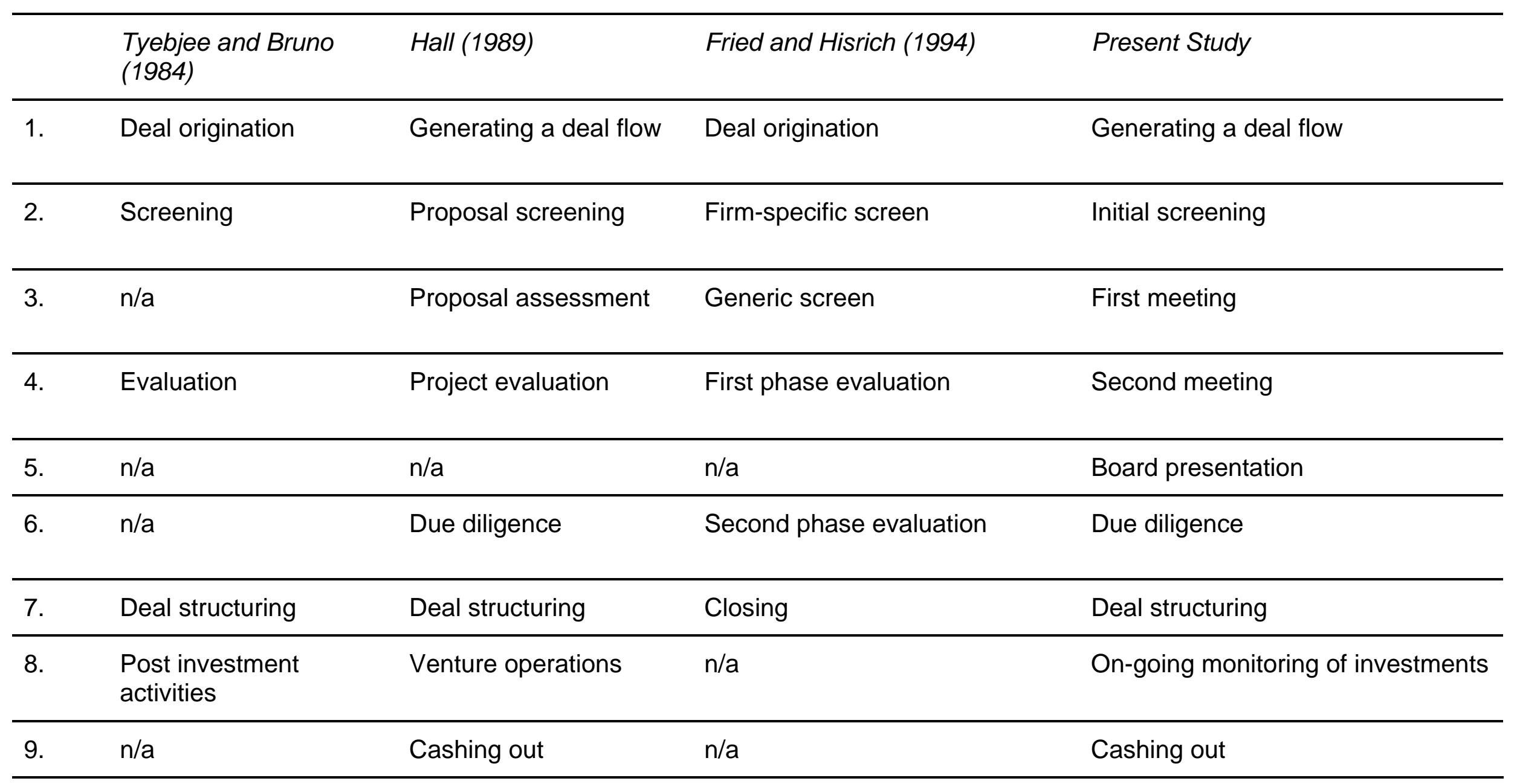

Lines are used to separate different stages in the cycle

Source: Adapted from Hall and Hofer (1993), Table II, p. 28. 


\section{Evaluation Criteria}

Venture capitalists are conspicuously successful at selecting new growth ventures (Bruno and Tybejee, 1983; Bygrave and Timmons, 1992), an outcome which suggests that appropriate selection criteria are utilised. A "modest degree of convergence" (MacMillan et al., 1987, p134) is evident in the evaluation criteria identified in key previous studies and the current research. These criteria are collated in Table 2. [N.B. Table 2 employs the format introduced by Hall and Hofer (1993), with amendments to reflect the fact that key factors cited by the original authors appear to have been omitted by Hall and Hofer.]

Tybejee and Bruno (1984) viewed the investment decision as a balancing act between negative ("risk") and positive ("return") factors. Negative factors such as weak management resulted in the rejection of proposals, while positive factors including attractive market conditions were essential for acceptance.

MacMillan et al. (1985) cited the most important evaluation criteria as the entrepreneur's personality and experience rather than product or market factors. The core issue for attracting finance was whether the plan demonstrated that the "jockey was fit to ride". Unfortunately, the way in which venture capitalists could accurately measure the required managerial capabilities was not specified. Using the same normative approach, Dixon (1991) confirmed the importance of entrepreneurial skills for UK venture funds.

The studies above examined evaluation criteria from an ex ante perspective, an approach which was also taken in the present study. However, the core factors for the Fund (set out in the final column of Table 2) extended beyond the characteristics and skills of the entrepreneur to encompass a whole range of issues, including fundspecific requirements and market factors. This outcome appears to reflect commercial reality. The success of any business depends upon the interaction of a number of factors; for example, an attractive product is necessary, but good management is also vital. The findings of ex post studies on evaluation criteria confirm the importance of non-managerial factors. 
TABLE 2: Findings on Venture Capitalists' Investment Criteria

\begin{tabular}{|c|c|c|c|c|c|}
\hline \multirow[b]{2}{*}{ Investment Criteria } & \multicolumn{3}{|l|}{ USA } & \multicolumn{2}{|l|}{ UK } \\
\hline & $\begin{array}{l}\text { Tyebjee and Bruno } \\
\text { (1984) }\end{array}$ & $\begin{array}{l}\text { MacMillan } \\
\text { et al. (1985) }\end{array}$ & $\begin{array}{l}\text { MacMillan } \\
\text { et al. (1987) }\end{array}$ & $\begin{array}{l}\text { Dixon } \\
(1991)\end{array}$ & $\begin{array}{l}\text { This } \\
\text { study }\end{array}$ \\
\hline \multicolumn{6}{|l|}{ Venture capital firm requirements } \\
\hline \multicolumn{6}{|l|}{ Cash out potential } \\
\hline \multicolumn{6}{|c|}{ Familiarity with technology, product, market } \\
\hline \multicolumn{6}{|l|}{ Financial provision for investors } \\
\hline \multicolumn{6}{|l|}{ Geographic location } \\
\hline \multicolumn{6}{|l|}{ Size of investment } \\
\hline Stage of development & $x$ & & & & $x$ \\
\hline \multicolumn{6}{|l|}{ Characteristics of the proposal } \\
\hline \multicolumn{6}{|l|}{ Requirement for additional material } \\
\hline \multicolumn{6}{|c|}{ Characteristics of the entrepreneur/team } \\
\hline \multicolumn{6}{|l|}{ Ability to evaluate risk } \\
\hline \multicolumn{6}{|l|}{ Articulate re: venture } \\
\hline \multicolumn{6}{|l|}{ Capable of sustained effort } \\
\hline \multicolumn{6}{|l|}{ Managerial capabilities } \\
\hline \multicolumn{6}{|l|}{ Marketing skills } \\
\hline \multicolumn{6}{|l|}{ Financial skills } \\
\hline \multicolumn{6}{|l|}{ Stake in firm } \\
\hline \multicolumn{6}{|l|}{ Nature of the proposed business } \\
\hline \multicolumn{6}{|l|}{ Product/market considerations } \\
\hline \multicolumn{6}{|c|}{ Economic Environment of proposed business } \\
\hline \multicolumn{6}{|l|}{ Market attractiveness } \\
\hline \multicolumn{6}{|l|}{ Potential size } \\
\hline \multicolumn{6}{|l|}{ Threat resistance } \\
\hline \multicolumn{6}{|l|}{ Strategy of the proposed business } \\
\hline Product differentiation & $\underline{x}$ & & & & \\
\hline
\end{tabular}


Proprietary product

Source: Adapted from Hall and Hofer (1993 p27) 
In examining the performance of investee companies, MacMillan et al. (1987) found the most important factors for success to be demonstrated market acceptance of the product and insulation against competitive attack. These "market" factors should perhaps have featured more strongly in the evaluation criteria identified in ex ante studies, especially as such factors appear to be easier to assess on an objective basis than the entrepreneur's personality or experience.

Rah et al. (1994) tried to overcome potential methodological flaws in the MacMillan studies by studying the same propositions from an ex ante and ex post standpoint. Three separate investment models were developed, two ex ante and one ex post. Market attractiveness was found to be the prime concern in the two pre-investment models, whereas the most influential factor on venture performance was managerial capability.

Overall, managerial and market factors have been consistently recognised in the literature on the investment cycle, but there have been variations in the weightings given to individual criteria. One explanation for these differences is that the venture capitalists' decision-making process may not have been fully captured because of methodological shortcomings in previous studies.

Doubts on the legitimacy of research data were cited above (MacMillan et al., 1985). Comparisons between evaluation criteria used at different stages of the decisionmaking process may have generated some spurious results. In studies which have emphasised market issues (Rah et al., 1994) or entrepreneurial characteristics (MacMillan et al., 1985; and Dixon, 1991), the respondents may not have specified the stage at which particular criteria are relevant. On a different theme, Sandberg et al. $(1988$, p9) stated that prior research has "failed to capture and convey the richness, subtlety and discernment embodied in the venture capitalist's decision process and criteria". These separate concerns were combined in the suggestion that future research has to move from a "single-stage, single set of criteria to the more complex and realistic perspective of a multi-stage, multi-criteria and multiperson decision" (Hall and Hofer, 1993, p40). 
Given the potential limitations of research in this field, it is important to describe in detail how the evaluation criteria used by the Midland Enterprise Fund were identified. Information was collected from the fund managers' working notes and/or final reports on the plans submitted. The final reports were summaries of the fund managers' views in relation to the applications. Even though the vast majority of applications were rejected, it was relatively straightforward to extract the positive factors sought by the fund managers - a rejection on the grounds of "No Unique Selling Point (USP)" clearly implies that the presence of an USP is a desirable feature. The key factors sought by the fund managers are included in the final column of Table 2.

Applications were rejected for failing to meet one or more of the fund managers' evaluation criteria; all the factors cited for the rejection of every application were collated from the working notes/final reports. These factors were then aggregated. To be classed as a "key factor" for the Fund (i.e., to merit an "X" in Table 2), a criterion had to account for more than 10 percent of the aggregate number of factors cited by the fund managers. This frequency of citation ensures the exclusion of isolated comments applying to individual applications.

Critically, the current study analyses the evaluation criteria through all stages of the decision-making process, recording the real time "gut feelings" and subjective views of the fund managers. (This approach goes some way towards countering the methodological issues raised above by MacMillan et al. and Sandberg et al.) Our study has therefore generated a list of key criteria which links with, but is more extensive than, that suggested in the literature.

The range of criteria utilised by the Fund reflects the fact, as stated above, that the success of any business depends upon the interaction of a number of factors. While it is acknowledged below that a rejection might stem from an accumulation of negative observations, detailed analysis of the applications submitted to the Fund reveals that the decision to accept or reject a proposition tends to hinge on a single issue. The identification of these dominant factors forms the next section. 


\section{Analysis of Rejections by The Fund}

The figures in Table 3 below are based on the prime reason for the rejection of each application (whereas Table 2 aggregates the factors cited for the rejection of all applications). The first-named reason for rejection was extracted from the final report lodged with each application, on the grounds that the most critical observation would be placed at the top of the list ${ }^{5}$.

TABLE 3: Reasons for Rejection of Proposals Received During the First Two Years of the Fund

Reason For Rejection

Incomplete Plan

Market Characteristics

Lack of Unique Selling Point

Start Up Finance

project Size inappropriate

Management Skills/Experience

Excessive Risks

Financial Factors

Application Withdrawn

Other

Total

Total Applications

Decision-making process completed

Investments Made

Investment Ratio

Applications Ongoing
Number Rejected Percentage

63

31

$26 \quad 13$

$8 \quad 4$

15

16

13

13

5

22

$\frac{22}{203}$

232

206

3

$1.46 \%$

26 
The reasons for rejection include those associated with the application of the Fund's evaluation criteria, as well as those stemming from the timescale involved in the decision-making process.

On the basis of frequency of citation, with no judgement on the weight attached to these factors, four broad categories accounted for the majority of rejections:

\section{a) Incomplete plan}

An incomplete plan is defined as one where key data were omitted from the original submission and the proposal was deemed unworthy of further investigation. Incomplete plans invariably failed, to a greater or lesser degree, to comply with the Guidance Notes (refer to the Appendix) sent to all enquirers. The quality of the application was seen by fund managers as a definite indicator of managerial competence and attention to detail. One application comprised a twelve month cashflow projection and nothing else, another consisted of a handwritten business plan on a single sheet of A5 paper.

If the plan was substantially "incomplete", the application was usually rejected quickly, with no requests for further information being made. There were a minority of cases where insufficient information was provided in the business plan, but omissions of key data were tempered by the level of perceived market potential stemming from a unique product. In such situations, the Fund adopted a proactive approach by calling for more evidence. In cases where no unique selling point (USP) was obvious, the absence of any market research or information on growth prospects would inevitably lead to rejection.

It was observed by the M/D that plans submitted by intermediaries were rarely rejected on the grounds of incompleteness. However, such applications were not always of high quality. Some intermediaries (including solicitors) seemed to fail to understand the role of venture capitalists, whilst others, notably accountants, placed excessive emphasis on financial projections. The Guidance Notes (Appendix) state that expert advice is useful, but stress: "Your plan should reflect you and your business ... it should be prepared by you and not by an advisor". The evidence from 
this Fund appears to confirm the widely held view that passing sole responsibility for the formulation of a business plan to an intermediary is not advisable.

b) Market characteristics

Once again, the scope of this category was quite wide, illustrated by a selection of quotes from the fund managers' working notes:

- "market too narrow and specialised to have significant growth prospects"

- "mature and contracting market"

- " "market saturated"

- $\quad$ "insufficient growth potential"

The lack of an USP was designated as a separate category for rejection, although it is clearly a market-related issue. The two categories of market characteristics and USP in Table 3 were very important factors, accounting for 34 out of 203 rejections (almost 17 percent).

c) Restrictions imposed by the Fund

The aim of the fund managers was to realise a number of investments reasonably quickly, in order to recycle a proportion of the original capital invested in the Fund. For this reason, investments in start-up businesses were limited to 15 percent of the investment pool. A number of potentially attractive start-up deals were therefore turned aside. Other applications were simply too big for the Fund, even when the possibility of syndication was taken into account. These two reasons accounted for 31 out of 203 rejections (over 15 percent).

\section{d) Application withdrawn}

In some cases, the applicants were not prepared to comply with the due-diligence procedure. The cost of due diligence was not a deterrent to applicants, because the philosophy of the Midland Enterprise Funds is to offer subsidised professional services (McMeekin, 1991). For the Fund in the East Midlands, a support network of 
professional firms was in place, but the M/D and Board of MVFML usually possessed the requisite expertise to conduct the due diligence "in-house". A more frequent reason for withdrawal was changing circumstances which meant that the funds were no longer required, for example buy-out bids that failed. In addition, a number of attractive propositions were denied to the Fund because the applicants were able to raise funds elsewhere on more favourable terms; 6 withdrawals (of 22 withdrawals in all) arose because the firms had access to alternative, preferred funding. (If "good" projects tend to be funded by a reasonably competitive market for venture capital, this raises the interesting question of whether the equity gap for small scale investments might only apply to "weak" propositions.)

\section{e) Other Reasons for Rejection}

Apart from the four dominant categories described above, rejections also stemmed from a variety of reasons - grouped under the "other" heading in Table 3 - generally where management problems were revealed, or where the applicant was unable to persuade others to invest alongside the Fund. Sample comments from the Fund's internal records included:

- "complementary finance in the overall funding package was not forthcoming"

- $\quad$ "managers turned up late for meetings after obviously going to the pub beforehand"

- "no response to requests for further information" (a comment which applied to a number of proposals)

As already stated, findings based on the above categorisation have to be interpreted with a degree of caution because applications were often rejected for a combination of reasons or on the overall impression created by the business plan. For example, rejections on the grounds of "excessive risks" in Table 3 usually reflected the fact that doubt had arisen in a number of other areas. This interaction between criteria also helps to explain why some factors appeared to be less important than might have been anticipated.

A key concern for the Fund, growth potential, seldom featured in the fund managers' 
working notes; this consideration is typically captured in the categories of "market characteristics" or "incomplete plan". Likewise, rejections rarely resulted directly from "financial factors", including the analysis of financial statements and projections; this finding has been prevalent in previous studies (Dixon, 1991). However, the fund managers did use financial projections to ascertain market attractiveness and cashout potential.

TABLE 4: Reasons for Rejection of Proposals received during the first two years of the Fund

\begin{tabular}{|l|r|r|r|r|r|}
\hline & $\begin{array}{r}\text { At initial } \\
\text { screening }\end{array}$ & $\begin{array}{r}\text { After 1st } \\
\text { meeting }\end{array}$ & $\begin{array}{r}\text { CUM } \\
\text { TOTAL }\end{array}$ & $\begin{array}{r}\text { After 2nd } \\
\text { meeting }\end{array}$ & $\begin{array}{r}\text { FINAL } \\
\text { TOTAL }\end{array}$ \\
\hline Incomplete Plan & 59 & 2 & 61 & 2 & 63 \\
Market Characteristics & 25 & 1 & 26 & - & 26 \\
Lack Of Unique Selling & & & & \\
$\quad$ Point & 8 & - & 8 & - & 8 \\
Start Up Finance & 12 & 2 & 14 & 1 & 15 \\
Project Size & 14 & 1 & 15 & 1 & 16 \\
Management Skills/ & & & & \\
$\quad$ Experience & 8 & 2 & 10 & 3 & 13 \\
Excessive Risks & 10 & 1 & 11 & 2 & 13 \\
Financial Factors & 5 & - & 5 & - & 5 \\
Application Withdrawn & 8 & 2 & 10 & 12 & 22 \\
Other & 13 & 4 & 17 & 5 & 22 \\
\hline Total & 162 & 15 & 177 & 26 & 203 \\
\hline
\end{tabular}

The closest parallel to our research in the UK is an examination by Mason and Harrison (1995) of the reasons why a group of informal investors rejected applications. (This work is particularly relevant as, it will be recalled, the Midland Enterprise Funds aim to liaise closely with business angels.) That study confirmed (p.47/8) that "most investment opportunities are rejected for just one or two key reasons", and it also highlighted "the importance of a flawed or incomplete marketing 
strategy and flawed or incomplete financial projections as significant deal killers". While informal investors emphasise the value of marketing factors, they appear to place more weight on the ability of the entrepreneur/management team and finance factors than the venture capitalists in our study. This apparent inconsistency probably stems from the fact that the latter two categories tend to be subsumed within our classification of "incomplete plan".

The interaction between the decision-making process and evaluation criteria is now further explored, by classifying the reasons for rejection or withdrawal of applications at three key stages within the investment cycle.

\section{Evaluation Criteria within the Fund's Decision-Making Process}

When an application is received by the Fund, it progresses through the decision making process until a flaw is identified which, on its own or in combination with others, leads to rejection. It is critical to note that such flaws occasionally did not appear until the final stages of the decision-making process, after completion of the due diligence process or when the funding agreement was ready for signature. Our detailed findings indicate that the criteria for rejection change as the application progresses (confirming the findings of Mason and Harrison, 1995). The analysis is therefore more comprehensive than Hall and Hofer (1993) who focused solely on the initial screening and assessment of business plans.

Our results are summarised in Table 4, an extended version of Table 3. The latter revealed a very high level of rejections; Table 4 shows that the vast majority of these occurred at the initial screening stage.

The reasons for rejection are categorised at three key stages in the decision-making process.

Screening Stage: inadequate information was the primary cause of rejection, resulting in 59 of 162 rejections (36 percent). (Hall and Hofer, 1993, p34, also found this factor to be the principal explanation for rejection at screening.) Market 
characteristics, such as poor market conditions or the lack of an USP, were also important. Crucially, the fund managers could establish relatively quickly whether these criteria were satisfied. By contrast, issues requiring further probing - such as business strategy, financial factors and entrepreneurial characteristics - were relatively unimportant in the initial screening.

The M/D and directors of the fund management company drew upon their wide experience of dealing with local industries (manufacturing and service) and their knowledge of the regional economy to decide whether a business had potential. This again confirms the findings of Hall and Hofer (1993, p35); 40 percent of rejections in that study arose because the fund managers applied intuitive logic, for example: “... I have rejected other proposals in this business/industry and there is nothing in this proposal to indicate that it is different".

First Meeting Stage: applications which progressed to this point failed to win backing for a variety of reasons, illustrated by the fact that "other" reasons accounted for 4 out of 15 rejections, for example:

- $\quad$ a weak member of the management team and some uncertainty regarding growth potential

- $\quad$ excessively slow response to requests for further information

- $\quad$ perceived inability of the fund managers and the management team to work in harmony; compatibility between the two parties is essential to the long term success of the investment.

A small number of applications (2) were withdrawn at this stage, when the meeting revealed that better working capital management by the applicant company would remove the need for funding.

Second Meeting (and Subsequent) Stage(s): the application was receiving very careful consideration and an investment offer was imminent. Market-related factors had already been appraised and deemed to be satisfactory - Table 4 shows no rejections on these grounds. However, as propositions were investigated in more depth, "other" problems which were not immediately obvious began to surface; for 
example, a failure to disclose the previous involvement of the directors in insolvency proceedings. This sort of information cannot easily be obtained at the screening stage.

A major concern was that a large proportion of applications reaching this stage (12 out of 26) were withdrawn. This was clearly a source of frustration for the Fund, as time and resources had been devoted to ultimately fruitless applications. A number of withdrawals stemmed from changes in business circumstances (hence delaying the time the funds would be required or resulting in the abandonment of the proposal) and a dislike of the due-diligence procedure. Other applicants were able to raise funds elsewhere on more favourable terms. This is valuable information for both academics and practitioners.

These late switches may have occurred because the fund managers were looking to back lower risk, typically asset-backed, companies in their first few deals, leaving scope for potential investee companies to negotiate with other providers. Although individual deals have to remain confidential, we are aware that entrepreneurs were able to retain more control over their company by utilising, for example, the Loan Guarantee Scheme, soft loans from British Coal Enterprises or business angels for equity and/or preference shares. (Research suggests that business angels make quicker decisions than venture capital funds: Freear and Wetzel, 1992.)

The time taken by the Fund to process applications varied over the period of the research. In the early months of its operations, the applications were generally weak, hence the vast majority were rejected during initial screening within a few days of being received by the Fund. At the end of the first six months of operation, for example, only one application had taken more than three months to process. When higher quality applications warranting further investigation started to arrive, investment decisions frequently took several months. Delays typically stemmed from the time involved in the production of due diligence reports or waiting for applicants to respond to requests for further information. By the end of the research period (two years), 26 applications were under investigation. Of these 26, 18 had been outstanding for under three months, 3 between three and six months, and 5 over six months. For many firms seeking venture finance, a quick decision is crucial in 
enabling them to seize a market opportunity, and speed may be more important than the terms and conditions of the investment.

The withdrawal of promising applications raises important issues, not only for the Fund, but also for the venture capital industry as a whole. If good investments are hard to come by, then withdrawals may indicate some faults in the decision-making process. Problems may initially stem from imperfect information, with applicants not fully understanding the nature of venture capital. More generally, venture funds may be advised to speed up their procedures for processing applications, in order to retain potentially sound investments. (The Fund described here did implement such action.) Although we could not establish a statistically significant link between withdrawals and the length of time an application had been in progress, informal discussions with fund managers indicated that the timescale was one of the factors that resulted in withdrawals.

A Chi-Squared test was used to establish whether there were significant differences between the reasons for rejection at each of three stages. Based on the cumulative totals at a 5 percent level, the results indicated no significant differences. This would suggest a certain consistency of approach as applications are processed. Although the overall pattern of reasons for rejection is broadly consistent, the dominant reason for rejection alters. However, sample observations are inadequate to allow us to test whether changes in the frequency of any single criteria at any single stage are significant.

The distinction between rejection at the screening versus first or second meeting stages can be further demonstrated with a selection of quotes from the Fund's internal records - see Table 5 (overleaf). 
Table 5: Reasons for Rejection during the Decision-Making Process

STAGE:

PRIME REASON FOR

REJECTION:

SAMPLE COMMENTS

[Quotes from Fund's records]

STAGE:

PRIME REASON FOR

REJECTION:

SAMPLE COMMENTS:

STAGE:

PRIME REASON FOR

REJECTION:

SAMPLE COMMENTS:
Initial screening

Incomplete plan

No technical specification; no

description of operation. Poor plan.

No clear breakdown of requirements, financial structure and market.

Growth potential doubt.

Capital base unrealistic for a very competitive market. No input from directors. No CVs. Directors starting business after previous failure.

Very competitive market. High risk startup. USP not obvious.

First Meeting

No Dominant Reason

Appears to have some potential but funds are not required for some time.

Doubts about market. Further investigations cast doubt over management ability.

Second Meeting

Applications Withdrawn

Directors received an alternative offer of finance.

Application withdrawn following poor sales figures for the last quarter.

Originally rejected due to weak balance sheet. Traded out of difficulties, but needs changes in the management structure which are unlikely to happen. 
We can now develop a simple model of the Fund's investment cycle, linking the evaluation criteria to specific stages in the decision-making process. This issue has rarely been tackled in previous studies.

The legitimacy of a model based upon the study of a single fund might be questioned. Robinson $(1987, \mathrm{p} 73)$ postulated that fund managers would remain virtually uniform in their evaluation criteria, despite operating in an increasingly differentiated industry. This contention was dismissed as "uninformed speculation" Sandberg et al. (1988, p12); these researchers acknowledged consensus in the identity of the venture capitalists' criteria, but stressed that different fund managers could apply different weights to the same criteria. Sweeting (1991, p613) found a high degree of uniformity across venture funds in the "mechanics" of processing applications, although the funds took differing perspectives on certain issues during their in-depth evaluations.

We do not suggest that the policies of the Fund studied here can be developed into a definitive model of venture capitalists' behaviour, but we are convinced that the detailed study of a single fund offers a useful contribution to the academic debate.

\section{A Model of the Decision-Making for the Fund}

Research work in this field has tended to focus on the development of ex ante models of investment behaviour, either normative or evaluation models. The latter are derived from the assessment of actual propositions. Alternatively, performancebased models have assessed the success or otherwise of investee companies. Our model falls into the ex ante evaluation category, as the empirical data relate to specific deals before the decision to accept/reject an application was made.

The dominant evaluation criteria at each stage of the decision-making process is summarised overleaf: 
1. Generating a Deal Flow: no decision required

2. Initial Screening: a full plan suggesting that a business has an USP and high growth potential.

3. First Meeting: a capable, credible management team; and the right "chemistry" between the fund managers and the management of the potential investee company.

4/5. Second Meeting/Board Presentation: confirmation of management skills, business growth potential and the financial elements of a proposition.

6/7. Due Diligence/Deal Structuring: financial and personal history - any skeletons in the cupboard?

In the final stages of the investment cycle (monitoring of investments and cashing out), the fund managers will be most concerned with patterns of growth in evidence and any divergence from plans.

The four investments actually completed (which satisfied the above criteria) were companies in very diverse industries: a sub-contract packing service, specialising in consumer products that require hand finishing; the application of new technology to the manufacture of environmentally-friendly cleaning, maintenance and horticultural chemicals; a manufacturer of industrial doors and shutters; and a dual-franchise car dealership located on a greenfield site.

An investment ratio of approximately 2 per cent clearly involves much work to identify potential investee companies. The M/D of the fund management company holds the view that venture capitalists have to kiss a lot of toads before finding a prince, and also that completing the "pre-kiss courtship" (seeing the toads in a true light!) can prove very time consuming and frustrating. 


\section{Conclusion}

The study conducted for this paper has a distinct advantage over other studies, because it analyses "real time" investment decisions made by a single fund over a two year period. Our findings offer four contributions to research in this field.

First, our research confirms the venture capitalists' decision-making process is multistaged.

Second, our study (and literature survey) suggests that entrepreneurs essentially have to satisfy broadly similar selection criteria to secure venture funding whichever fund is approached. These criteria can be classified under a few key headings:

- the specific requirements of the individual fund (size of investment, location of firm, etc)

- the market for the product, notably the degree of competition in, and the growth potential of, the market

- management skills and commitment.

Third, and most importantly, the experience of the Fund suggests that the academic debate on the relative significance of different evaluation criteria may have little relevance for practitioners. For example, there is probably no real difference of opinion among fund managers on whether market potential matters more than entrepreneurial skills, even though studies dealing with the initial screening stage might suggest that venture capitalists concentrate on the former at the expense of the latter. In our analysis of the Fund's operations, we did not attempt to measure the precise weights applied to specific criteria as applications are progressed. However, it was apparent that different criteria were considered at each successive stage of the decision-making process. 
This theme is developed in our fourth finding. Our model demonstrates that it is not possible to deal independently with the two issues of the decision-making process and evaluation criteria. Time is at a premium, and each venture fund develops a system to eliminate weak applications in an efficient manner. Initially, the venture capitalist's main role is to decide which proposals are worthy of further investigation. Some defects are easier to detect than others - the lack of a unique selling point, will soon be evident, whereas it will take time to establish (say) that a company seeking funds has a management team which can work in harmony with the fund managers. Market factors are therefore evaluated at an early stage, whereas criteria relating to entrepreneurial characteristics and financial factors do not appear to be critical until a proposal has progressed beyond the screening stage.

Further research would serve to clarify the nature of the link between evaluation criteria and the specific stages of the decision-making process. It would also be helpful to establish whether the model developed for a single is applicable to other funds, and to track the success or otherwise of the Fund's investee companies, thereby moving to a performance-based model.

Finally, one observation from the research which should be brought to the attention of practitioners is the fact that so many applicants withdraw at a late stage. The speedy processing of applications is vital to retain attractive investee companies. The number of late withdrawals also suggests the need for flexibility in structuring the deal, and a willingness to renegotiate if an alternative offer is received from elsewhere. Otherwise, there is a risk of high staff costs being incurred in achieving a relatively low investment rate. 


\section{Appendix: Applications to the Midland Enterprise Fund}

\section{GUIDANCE NOTES ON PREPARING A BUSINESS PLAN [EXTRACTS]}

The Fund is only able to accept applications in the form of a comprehensive Business Plan. Every business is unique and so is every Business Plan. Your plan should reflect you and your business and because of this it should be prepared by you and not by an advisor. It is always useful to get expert advice but you must be able to answer any question about the plan. Remember that there are several sources of help in preparing a business plan - in particular your local Training and Enterprise Council has made arrangements to provide free or subsidised business advice and information.

\section{KEY AREAS OF FOCUS}

\section{Management}

You need to demonstrate that your team has the management skills needed to run the business and make the most of the opportunities you have identified. Include a comprehensive $\mathrm{CV}$ for each of the key members of your team.

\section{Market}

Prove that there is a real market for your products or services and that you can meet its requirements. Market research, past sales figures and letters of interest from prospective customers are all valuable evidence.

\section{Finance}

Show how much money you will need (cash flow projections), the profit you expect to make (profit \& loss projection) and what assets the business has (current and projected balance sheets). Past accounts are essential for established businesses and there should be no significant gap between those and the start of the projections.

Please remember that our decision to take your application further will be made on the basis of your business plan and if any of these key areas are not adequately covered it will put your proposal at a considerable disadvantage. 


\section{Postscript}

With effect from 1 July 1997, The Midlands' Enterprise Fund was launched from the merger of The Midland Enterprise Fund for the East Midlands with The Midland Enterprise Fund for the West Midlands. Midland Bank plc has provided a further $£ 2$ million, increasing the size of the new fund to $£ 4.5$ million. Midlands Venture Fund Managers Limited remain as Fund Managers. The present Managing Director is John O'Neill.

\section{Notes}

Due diligence, according to the Financial Services Act, involves checking all the information deemed to be "necessary" for an application; the amount of detail required will clearly vary between (say) a £5m and £5,000 deal

${ }^{2}$ The decision-making process incorporates the initial screening and evaluation of an application for funding and also the subsequent appraisal process, up to the point where a final decision is made by the Fund on whether to reject or accept the proposition; the process also includes confirmation that the terms of the proposed deal are acceptable to all parties

The investment cycle includes the generation of applications, the complete decision-making process and also the management and liquidation of an investment. ${ }^{4}$ The evaluation or selection criteria are the factors considered in the initial screening of an application and later appraisal stages

${ }^{5}$ The fund managers confirmed that the first-named reason did not simply reflect the ordering of the material in the application, and that it represented their personal view - not a sanitised justification of the decision to outsiders. 


\section{Acknowledgements}

The authors are very grateful to Kevin Caley, former Managing Director of Midlands Venture Fund Managers Limited, the fund management company of the Fund. He and his support team gave the authors every encouragement in compiling the data for this article, although the responsibility for interpreting the data remains solely with the authors. In addition, the authors benefited from helpful comments on earlier drafts of this paper by Professor Ian Morison at Loughborough University and an anonymous referee.

\section{REFERENCES}

ACOST - Advisory Council on Science and Technology (1990), The Enterprise Challenge: Overcoming Barriers to Growth in Small Firms. HMSO, London. Bannock, Graham and Partners Ltd. (1991), Venture Capital and the Equity Gap. Graham Bannock and Partners Ltd.

Boocock, J. G., Woods, M. M., and Caley, K. (1995), "The Equity Gap in the East Midlands: An Initial Assessment of the Operation of a New Venture Capital Fund". In: Chittenden, F. et al. (eds) Small Firms: Partnerships for Growth. London: Paul Chapman Publishing Ltd, pp1-48.

British Venture Capital Association - BVCA. (Various), Annual Report on Investment Activity.

Bruno, A. V., and Tybejee, T. T. (1983), "The one that got away: A study of ventures rejected by capitalists". In: Hornaday, J. A. et al. (eds), Frontiers of Entrepreneurship Research. Proceedings of 1983 Conference on Entrepreneurship, Wellesley, MA: Babson College, pp289-306.

Bygrave, W. D., and Timmons, J. A. (1992), Venture Capital at the Crossroads. Harvard Business School Press, Mass, US.

Dixon, R. (1991), "Venture Capitalists and the Appraisal of Investments". Omega, 19 (5), pp333-344.

Freear, J., and Wetzel, W.E. (1992), "The Informal Venture Capital Market in the 1990s". In Sexton, D.J and Kasarada, J.D. (eds), Entrepreneurship in the 1990s, Boston: PWS-Kent, pp 462-486. 
Fried, V. H., and Hisrich, R. D. (1988), "Venture Capital Research: Past, Present and Future". Entrepreneurship Theory and Practice, Fall 1988, pp15-28.

Fried, V. H., and Hisrich, R. D. (1994), "Toward a Model of Venture Capital Investment Decision Making". Financial Management, 23 (3), Autumn 1994, pp 28-37.

Gorman, M., and Sahlman, W.A. (1989), "What Do Venture Capitalists Do?" Journal of Business Venturing, May, pp231-248.

Hall, H. J. (1989), Venture Capital Decision Making and the Entrepreneur: An Exploratory Investigation. Unpublished Doctoral Thesis. University of Athens, Georgia.

Hall, H. J., and Hofer, C. W. (1993), "Venture Capitalists' Decision Criteria in New Venture Evaluation". Journal of Business Venturing, 8, pp25-42.

Lorenz, A. (1989), Venture Capital Today, 2nd ed. Woodhead-Faulkner, London.

Mason, C. M., and Harrison, R.H. (1993), "Strategies for Expanding the Informal Venture Capital Market". International Small Business Journal, 11 (4), pp 2338.

Mason, C. M., and Harrison, R.H. (1994), "Informal Venture Capital in the UK". In: Hughes A and Storey D.J (eds), Finance and the Small Firm. Routledge, London, pp64-111.

Mason, C. M., and Harrison, R.H. (1995), "Why 'Business Angels' Say No: A Case Study of Opportunties Rejected by an Informal Venture Capital Syndicate". International Small Business Journal, 14 (2), pp 35-51.

McMeekin, D. (1991), "Finance for Enterprise: Closing The Equity Gap", Paper presented to the 14th National Small Firms' Policy and Research Conference, Blackpool. Unpublished.

MacMillan, I. C., Siegel, R, and Subba Narasimha, P. N. (1985), "Criteria Used By Venture Capitalists to Evaluate New Venture Proposals". Journal of Business Venturing, 1, pp119-128

MacMillan, I. C., Zemann, L. and Subba Narasimha, P. N. (1987), "Criteria Distinguishing Successful from Unsuccessful Ventures in the Venture Screening Process". Journal of Business Venturing, 2, pp123-137.

Norton, E. (1993), "Venture Capital Finance: Review and Synthesis", in Advances in Quantitative Analysis of Finance and Accounting, 2 (B), pp141-165. JAI Press Inc. 
Joondoug Rah, Kyungjin Jung and Jinjoo Lee. (1994), "Validation of the Venture Evaluation Model in Korea". Journal of Business Venturing, 9 (6), pp509-524.

Ray, D. M. (1993), "Pioneering Venture Capital in Developing Countries: Strategic Implications in South East Asia". Journal of International Business and Entrepreneurship, 2 (1), pp23-63.

Robinson, R. B. (1987), "Emerging Strategies in the Venture Capital Industry", Journal of Business Venturing, 2(1), pp53-77.

Sandberg, W. R., Schweiger, D. M. and Hofer, C. W. (1988), "The Use of Verbal Protocols in Determining Venture Capitalists' Decision Processes". Entrepreneurship Theory and Practice, Winter, pp8-20.

Silver, A. D. (1985), Venture Capital: The Complete Guide for Investors. New York: John Wiley and Sons.

Sweeting, R. C. (1991), "UK Venture Capital Funds and the Funding of New Technology-based Businesses: Process and Relationships". Journal of Management Studies, 28 (6), pp601-622.

Tyebjee, T. T., and Bruno, A. V. (1984), "A Model of Venture Capitalist Investment Activity". Management Science, 30 (9), pp1051-1066.

University of Cambridge, Small Business Research Centre. (1992), The State of British Enterprise: Growth, innovation and competitive advantage in small and medium-sized firms, Cambridge.

Warne, K.F. (1988), Essays on the Venture Capital Market, Yale University, Unpublished PhD Dissertation, cited in Barry, C.B. (1994) "New Directions in Research on Venture Capital Finance" Financial Management, 23 (3), Autumn 1994, pp 3-15 